\title{
Temporal patterns of biological dimethylsulfide (DMS) consumption during laboratory-induced phytoplankton bloom cycles
}

\author{
Mikhail Zubkov' ${ }^{1}$ Laura J. Linn ${ }^{2}$, Rudolf Amann ${ }^{3}$, Ronald P. Kiene ${ }^{2, *}$ \\ ${ }^{1}$ Plymouth Marine Laboratory, Prospect Place, Plymouth PL1 3DH, UK \\ ${ }^{2}$ Department of Marine Sciences, University of South Alabama, Mobile, Alabama 36688, USA, and Dauphin Island \\ Sea Lab, Dauphin Island, Alabama 36528, USA \\ ${ }^{3}$ Max-Planck-Institute for Marine Microbiology, Celsiusstrasse 1, 28359 Bremen, Germany
}

\begin{abstract}
Phytoplankton bloom cycles were followed for $9 \mathrm{~d}$ in two 201 carboy mesocosms filled with water from the offshore plume of Mobile Bay Alabama, USA, and incubated under fluorescent light. One of the blooms was enriched by addition of nitrate+phosphate (+nutrients), and both blooms were used to study how dimethylsulfide (DMS) concentrations and biological consumption varied over the bloom cycles. Peaks of algal biomass (15-22 $\mu \mathrm{g}$ chlorophyll $\mathrm{a}^{-1}$ ) in the blooms were followed within $1 \mathrm{~d}$ by peaks of the DMS precursor, particulate dimethylsulfoniopropionate (DMSPp; 100-140 nM). DMS concentrations increased rapidly during the early bloom, rising from $1 \mathrm{nM}$ on Day 1 up to $12 \mathrm{nM}$ in the unamended carboy and up to $17 \mathrm{nM}$ in the +nutrient carboy on Day 6 . Maximum values for DMS concentrations, DMS consumption rates (as measured with ${ }^{35} \mathrm{~S}-\mathrm{DMS}$ ), and bacterial production were observed during the early decline of phytoplankton biomass. DMS consumption rates were initially $0.8 \mathrm{nM} \mathrm{d}^{-1}$ and increased to $3.1 \mathrm{nM} \mathrm{d}^{-1}$ in the unamended carboy and to $9.1 \mathrm{nM} \mathrm{d}^{-1}$ in the +nutrient carboy. Rate constants for DMS consumption $\left(0.25-0.95 \mathrm{~d}^{-1}\right)$ initially decreased as DMS concentrations increased, resulting in longer turnover times for DMS during the peak and early decline of the blooms. Assimilation of DMS-sulfur by bacterioplankton accounted for $4-22 \%$ of the total DMS consumption and higher rates of DMS assimilation occurred in the +nutrients bloom. Despite a bloom and decline of total heterotrophic bacterial abundances, bacterial community composition at the major phylogenetic group level remained relatively constant in both blooms, although the alpha proteobacteria showed a temporal increase in abundance in the +nutrient carboy. The concentration ratios of DMS:chlorophyll a and DMS:DMSP displayed nonlinear, sigmoidal patterns over the bloom cycles and these ratios were not substantially affected by the nutrient amendment. Our results demonstrate that uncoupling of DMS production and biological consumption can occur early in a bloom cycle, causing DMS concentrations to rise significantly before biological consumption responds to draw down the DMS.
\end{abstract}

KEY WORDS: Nutrients · Sulfur cycle · Biogeochemistry · Gulf of Mexico · Climate · Bacterial metabolism · Uptake

Resale or republication not permitted without written consent of the publisher

\section{INTRODUCTION}

Many marine phytoplankton species produce large amounts of the intracellular osmolyte dimethylsulfoniopropionate (DMSP) (Keller et al. 1989), and high concentrations of DMSP are often observed in phyto- plankton blooms (Malin et al. 1993, Gibson et al. 1996, Matrai \& Vernet 1997, van Duyl et al. 1998). The production and biogeochemical cycling of DMSP in marine systems is of interest because this compound is an important source of carbon and sulfur in the microbial food web (Kiene et al. 2000, Simó et al. 2002), 
and also because DMSP is the major precursor of the volatile sulfur species dimethylsulfide (DMS) (Turner et al. 1988, Simó 2001). Marine DMSP cycling supports a global sea-to-air DMS flux of between 0.5 and $1 \mathrm{Tmol}$ $\mathrm{yr}^{-1}$ (Andreae 1990, Kettle \& Andreae 2000), with DMS emissions affecting atmospheric chemistry, and potentially climate, through formation of aerosols that scatter solar radiation and affect cloud optical properties (Charlson et al. 1987, Malin \& Kirst 1997).

The emission rate of DMS depends greatly on the concentration of DMS in surface waters which, in turn, is controlled by the relative magnitude of complex production and loss processes (Malin \& Kirst 1997). Although nearly all marine DMS arises from DMSP, DMS emission typically accounts for a very small part of the DMSP cycled in surface seawater (Bates et al. 1994). Recent investigations have shown that bacteria transform dissolved DMSP (DMSPd) not only into DMS but also into methanethiol (MeSH) (Kiene 1996a), a process that acts as a major control on DMS production. Microbial consumption of DMS also limits its flux to the atmosphere (Kiene \& Bates 1990), but it is now recognized that the relative magnitude of biological DMS consumption and other sinks (i.e. sea-air exchange and photolysis) can vary with time and location (Kieber et al. 1996, Simó \& Pedrós-Alió 1999b).

Elevated DMS concentrations have been observed during phytoplankton blooms in the field (Malin et al. 1993, Matrai \& Keller 1993) and in controlled mesocosm incubations (Nguyen et al. 1988, Kwint \& Kramer 1995, Kwint et al. 1996). Most often the highest DMS concentrations are associated with the decline phases of blooms when phytoplankton are senescing due to nutrient limitation, or are being intensively grazed (Nguyen et al. 1988, Kwint \& Kramer 1995). On the other hand, van Duyl et al. (1998) observed highest DMS concentrations during the early, exponential increase of phytoplankton biomass in a Phaeocystis sp. bloom. Obviously the production of DMS can become uncoupled from its consumption, but relatively few studies have examined the dynamics of DMS in relation to bloom development and decline. Because the magnitude of DMS flux to the atmosphere depends strongly on the concentration of DMS in surface waters (Andreae 1990), further knowledge is needed of the factors that control temporal variations in DMS concentrations under a variety of conditions.

Recently, a sensitive radioactive sulfur tracer technique has been developed and employed for measuring the rates of DMS turnover (Kiene \& Linn 2000a,b, Zubkov et al. 2001, 2002). In the present study we used this technique to follow DMS consumption in conjunction with changes in DMS concentrations, phytoplankton-associated parameters (chlorophyll $a$ and particulate DMSP) and bacterial parameters (biomass production and community composition) during 2 phytoplankton blooms, one of which was augmented by the addition of exogenous inorganic nutrients. The aim of this study was to gain greater understanding of the temporal development of biological DMS consumption, which is a major control on DMS concentrations in nature.

\section{MATERIALS AND METHODS}

Sample collection and incubation. Samples of surface water were collected from a small boat on April 21, 1999 directly into two 20 l, acid-rinsed, clear polycarbonate carboys at a site located approximately $10 \mathrm{~km}$ south of Dauphin Island, Alabama, USA $\left(30^{\circ} 20^{\prime} \mathrm{N}\right.$, $88^{\circ} 10^{\prime} \mathrm{W}$ ). This site was in the plume discharging from Mobile Bay into the northern Gulf of Mexico. Water samples (salinity $34 \mathrm{ppt}$ ) were held in the dark at in situ temperature during transit back to the laboratory $(<2 \mathrm{~h})$. To ensure a bloom in at least 1 of the carboys, nitrate and phosphate $\left(10 \mu \mathrm{M} \mathrm{NO}_{3}{ }^{-}, 0.65 \mu \mathrm{M} \mathrm{PO}_{4}{ }^{3-}\right.$ added concentrations) were added to 1 carboy upon return to the laboratory (Day 0). The other carboy remained unamended and therefore contained only endogenous nutrients, which were not measured until Day 1 . The carboys were incubated in an environmental chamber at the in situ temperature $\left(20^{\circ} \mathrm{C}\right)$. During the experiment, carboys were constantly mixed by a magnetic stirrer. Light $\left(70 \mu \mathrm{mol}\right.$ photons $\left.\mathrm{m}^{-2} \mathrm{~s}^{-1}\right)$ was provided by cool-white fluorescent bulbs with a day/night cycle of $14 \mathrm{~h}$ light and $10 \mathrm{~h}$ dark. The experimental light period was slightly longer than that in the field $(13.1 \mathrm{~h})$. Daily, for 9 consecutive days, $750 \mathrm{ml}$ subsamples were gently poured from the carboys, with minimal gas exchange, into receiving bottles. These subsamples were used for a series of analyses and incubations, described further below.

Analytical methods. Dissolved DMS in water samples was analysed by sulfur-selective gas chromatography as described by Kiene (1996b). We measured 3 analytical replicates (coefficient of variation, $\mathrm{CV}<8 \%$ ) from each carboy sample on each date. For $5 \mathrm{ml} \mathrm{sam-}$ ples the detection limit was $0.1 \mathrm{nM}$ DMS. Particulate DMSP (DMSPp) was measured on $50 \mathrm{ml}$ subsamples that were filtered by gravity through GF/F glass-fiber filters. The GF/F filters were treated with $2 \mathrm{ml}$ of $5 \mathrm{~N}$ $\mathrm{NaOH}$ in sealed vials and allowed to sit for $>12 \mathrm{~h}$ before analysis. The amount of DMS released into the headspace was quantified by injection of $100 \mu \mathrm{l}$ subsamples of the headspace into the gas chromatography-flame photometric detector (GC-FPD). Single DMSPp measurements from each carboy sample were made on most dates, but replicate analyses on a few dates showed that the coefficient of variation was 
$<10 \%$. Chlorophyll a (chl a) was measured fluorometrically (Strickland \& Parsons 1968) on $100 \mathrm{ml}$ subsamples collected on GF/F filters. Concentrations of nitrate were measured in GF/F filtrates by auto-analysis on an Alpkem model RFA/2.

We measured DMSPd concentrations and we also measured turnover rate constants for DMSPd with ${ }^{35} \mathrm{~S}-\mathrm{DMSPd}$. Inconsistencies in these data led us to suspect that filtration-induced release of DMSP occurred, leading to overestimation of DMSPd concentrations and hence calculated turnover. We therefore decided not to present the DMSPd data. Even though filtration artifacts probably increased the DMSPd concentrations significantly, the DMSPp concentrations were not substantially affected by the loss of DMSPd during filtration; DMSPd concentrations averaged $<10 \%$ of the measured DMSPp, which is within the precision of the DMSPp measurement.

Uptake and metabolism of DMS. We filled $60 \mathrm{ml}$ Teflon bottles ( 1 for each carboy) with sampled water and each bottle was spiked with gaseous ${ }^{35} \mathrm{~S}-\mathrm{DMS}$ to 50-1000 dpm $\mathrm{ml}^{-1}$. Isotope spikes varied from one incubation to the next, but these differences did not affect the determination of rate constants because all the additions were at non-perturbing tracer levels $\left(<0.1 \mathrm{nM}\right.$ of added $\left.{ }^{35} \mathrm{~S}-\mathrm{DMS}\right)$. These samples were incubated in the dark at $20^{\circ} \mathrm{C}$, and at selected times (typically at 5.5-8.5 h), 5-30 ml subsamples were taken and filtered through $0.2 \mu \mathrm{m}$ nylon filters for determination of total uptake of ${ }^{35} \mathrm{~S}$ into particulate material. For determination of dissolved non-volatile sulfur (DNVS) transformation products of ${ }^{35} \mathrm{~S}-\mathrm{DMS}$ (Kiene \& Linn 2000b), a $5 \mathrm{ml}$ subsample of the $0.2 \mu \mathrm{m}$

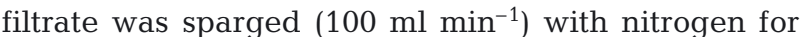
7 min to remove dissolved ${ }^{35} \mathrm{~S}-\mathrm{DMS}$, and the activity remaining in the sparged filtrate was radio-assayed. Tests with $0.2 \mu \mathrm{m}$-filtered seawater or time 0 controls of unfiltered water showed that sparging for 7 min was sufficient to remove $>99 \%$ of unreacted ${ }^{35}$ S-DMS. These tests also showed that nonbiological DMS consumption was negligible. Rate constants for DMS turnover due to uptake or transformation into DNVS were calculated from the fraction of DMS converted into the respective pools per unit time. The total DMS consumption rate constant was taken as the sum of the rate constants for uptake plus DNVS production. DMS consumption rate, in $\mathrm{nM} \mathrm{d}^{-1}$, was calculated by multiplying the total rate constant by the concentration of DMS at the time of sampling. The measured DMS consumption was biological because photochemical destruction was precluded by incubations in the dark, and abiotic DMS losses (either oxidation or loss to the gas phase) were insignificant.

Bacterial production and cell abundance. Production of bacterial biomass in subsamples of water col- lected on each sampling day was estimated from the incorporation of $\left[{ }^{3} \mathrm{H}\right]$-leucine (Kirchman et al. 1985) using a conversion factor of $3.1 \mathrm{~kg}$ of bacterial $\mathrm{C} \mathrm{mol}^{-1}$ incorporated leucine (Simon \& Azam 1989). The added concentration of leucine was $20 \mathrm{nM}$ (1 nM [ $\left.{ }^{3} \mathrm{H}\right]$-leucine and $19 \mathrm{nM}$ unlabeled leucine).

For bacterial abundance measurements, and for taxonomic identifications, $2 \mathrm{ml}$ subsamples were fixed with $1 \%$ formaldehyde and kept frozen at $-20^{\circ} \mathrm{C}$ for subsequent analyses. Abundance of total heterotrophic bacteria was determined with a FACStar Plus flow cytometer (Becton Dickinson) as described previously by Zubkov et al. (1999).

The abundance of several major bacterial taxonomic groups was determined by fluorescence in situ hybridization (FISH) on the same samples used for the flow cytometric counts of total heterotrophic cells. Bacteria from the thawed samples were collected on $0.2 \mu \mathrm{m}$ polycarbonate filters (Millipore). Fluorescence in situ hybridization of harvested cells counter-stained with DAPI was done according to a protocol of Glöckner et al. (1996). The following oligonucleotide probes were used: EUB368 (5'-GCTGCCTCCCGTAGGAGT-3'; specific for domain Eubacteria,), ALF968 (5'-CGTTCGYTCTGAGCCAG-3'; specific for alpha-subdivision of Proteobacteria), BET42a (5'-GCCTTCCCACTTCGTTT-3'; specific for beta-subdivision of Proteobacteria), GAM42a (5'-GCCTTCCCACATCGTTT-3'; specific for gamma-subsubdivision of Proteobacteria), CF319a (5'-TGGTCCGTGTCTCAGTAC-3'; specific for the Cytophaga-Flavobacterium cluster), according to Amann et al. (1995). All probes were commercially synthesized and labeled with indocarbocyanine dye Cy3 (Interactiva). The relative abundance of hybridized cells was estimated as the ratio of hybridized cell counts to counts of DAPI-stained cells using epifluorescence microscopy (Zeiss Axioplan microscope equipped with a $100 \times$ Plan Neofluor objective). We counted 300-500 DAPI-stained cells in each hybridized sample and the relative concentration of each group was calculated as the ratio of probepositive cells that also had a DAPI signal to the total number of DAPI-stained cells in an examined filter area. For most samples, only 1 filter was prepared for counting, but duplicate analysis of selected samples showed that the counting error did not exceed $3 \%$. The percentage of heterotrophic microbial cells that hybridized with a general eubacterial probe (Eub) was conservative, between 80 and $90 \%$ throughout the experiment. These percentages were used to estimate a maximum counting error, which was $5.4 \%$. Therefore the accuracy of microscopic FISH analysis should be better than $5.5 \%$. About $80 \pm 15 \%$ of Eub-positive bacteria were identified by one of the group specific probes used. In order to estimate absolute concentra- 
tions of each bacterial group, the ratios of probe-positive cells were multiplied by the total bacterial concentration determined by flow cytometry.

\section{RESULTS AND DISCUSSION}

\section{Bloom development}

Temporal patterns of phytoplankton-associated parameters (e.g chl $a$ and DMSPp) were similar in the 2 carboys (Fig. 1a,b). During the first $2 \mathrm{~d}$ of incubation phytoplankton biomass, as measured by chl $a$, in-

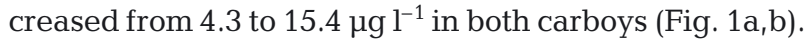
After Day 2, chl a began to decline in the unamended carboy, whereas it continued to increase in the +nutrient carboy, reaching a peak of $22 \mu \mathrm{g}^{-1}$ on Day 4 . The time at which both blooms began to decline corresponded with the exhaustion of nitrate in the respective carboys (Fig. 1a,b). By the end of the experiment, the chl a concentrations in both carboys $\left(\sim 5 \mu \mathrm{g} \mathrm{l}^{-1}\right)$ were nearly at the initial values. The magnitude of
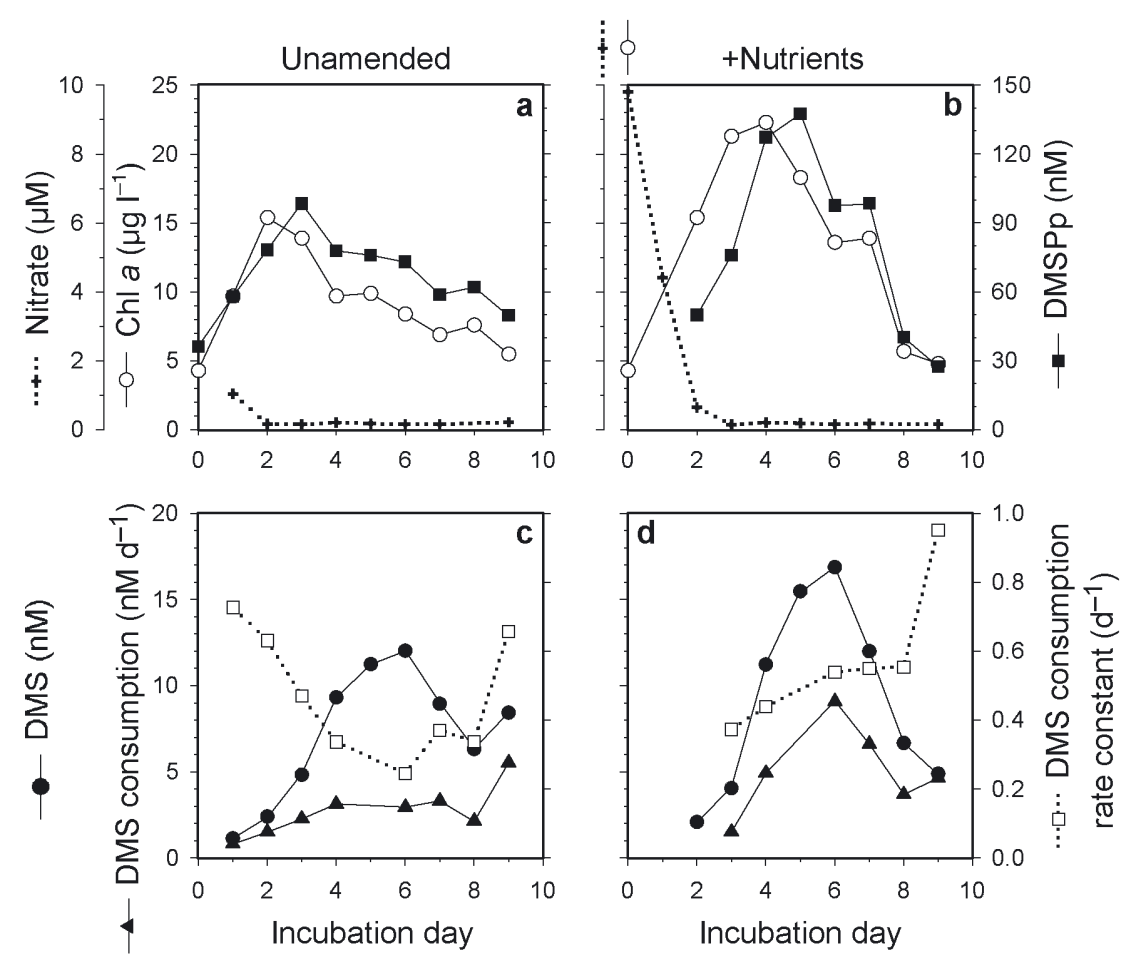

Fig. 1. Time-dependent changes in $(\mathrm{a}, \mathrm{b})$ chlorophyll $a$, nitrate and particulate DMSP (DMSPp) concentrations and (c,d) DMS concentrations, biological DMS consumption rate and total biological DMS consumption rate constant in 201 carboy mesocosms incubated without $(\mathrm{a}, \mathrm{c})$ or with $(\mathrm{b}, \mathrm{d})$ added nutrients. Water in the carboys was collected from the Mobile Bay (Alabama, USA) plume on Day zero of the experiment and nutrients were added upon return to the laboratory (Day 0). Incubation was at $20^{\circ} \mathrm{C}$ under fluorescent light $\left(70 \mu \mathrm{mol}\right.$ photons $\mathrm{m}^{-2}$ $\mathrm{s}^{-1}$ ). $y$-axis scale for nitrate concentration on left of figure applies to (a) and (b); for clarity, unlabelled version of same $y$-axis scale is shown between these 2 graphs these laboratory-induced blooms is typical of those which occur in the field as the Mobile Bay plume empties onto the shallow coastal shelf of the northern Gulf of Mexico (Pennock et al. 1999).

The DMSPp concentration was initially $36 \mathrm{nM}$ and it increased to a maximal value of $98 \mathrm{nM}$ on Day 3 in the unamended carboy (Fig. 1a). The increase of DMSPp in the +nutrient carboy lagged behind that of the unamended carboy, but eventually reached a higher maximal concentration (138 nM) on Day 5 (Fig. 1b). The highest DMSPp concentrations in both blooms occurred about $1 \mathrm{~d}$ after the peaks of chl a (Fig. 1a,b). uring the decline phases of the blooms, the DMSPp (n) closely the decreases of chl a chl a and DMSPp concentrations might be expected based on previous studies that have observed elevated concentrations of DMSPp and strong correlations between DMSPp and chl a in natural blooms of DMSPproducing phytoplankton (Malin et al. 1993).

The DMSP:chl a ratios (nmol:pg) ranged from 3.2 to 9.1 in both carboys throughout the experiment. These relatively low values are typical of coastal, diatom-dominated communities (Iverson et al. 1989), possibly as a result of the low intracellular DMSP concentrations in diatoms compared with some other taxonomic groups such as the dinoflagellates and prymnesiophytes (Keller et al. 1989).

Our 9 d sampling regime captured nearly a complete bloom cycle, with end-time concentrations of chl a and DMSPp returning nearly to those measured at the start of the experiment (Fig. 1a,b). The dynamics of the phytoplankton-associated parameters were accompanied by significant changes in the concentrations and microbial turnover of DMS, an important degradation product of DMSP.

\section{DMS concentration dynamics}

The concentration of DMS in the unamended carboy was about $1 \mathrm{nM}$ on Day 1 , and it increased rapidly during the bloom development, reaching maximum concentrations of 12 and 17 nM on Day 6 in the unamended and +nutrient carboys, respectively (Fig. 1c,d). The maximum DMS concentrations occurred $4 \mathrm{~d}$ after the chl a maximum (3 d after the DMSPp maximum) in the unamended 
carboy, but only $2 \mathrm{~d}$ after the chl a maximum (1 d after the DMSPp maximum) in the +nutrients carboy. After the peak DMS concentrations were reached on Day 6, they decreased rapidly in both carboys to about 5-8 $\mathrm{nM}$ by the end of the experiment on Day 9. These final concentrations were substantially higher than the initial concentrations despite relatively fast consumption of DMS at this time (see below). DMS concentrations in both carboys began to increase early in the blooms, before significant declines in DMSPp occurred. van Duyl et al. (1998) also observed high DMS concentrations early in a natural bloom of Phaeocystis sp. in the Dutch Wadden Sea. Phaeocystis sp. is known to produce a cell-surface DMSP lyase which might have been responsible for high DMS accumulations during the exponential growth phase of the Wadden Sea bloom (van Duyl et al. 1998). Unfortunately, without detailed information on the phytoplankton species composition in our study, we cannot say conclusively whether any DMSP lyase-producing phytoplankton species were abundant or not. Diatoms, which were probably dominant in our mesocosms, are not known to have active DMSP lyase enzymes (Steinke et al. 1996). The most likely source of DMS during the blooms was bacterial degradation of dissolved DMSP (Turner et al. 1988), although direct output from phytoplankton cannot be ruled out.
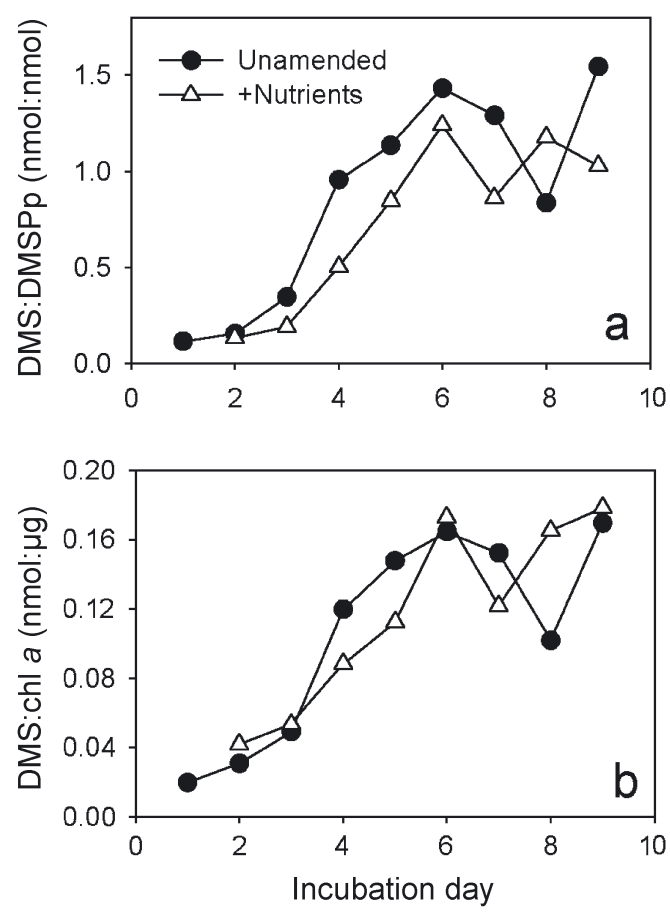

Fig. 2. Time-dependent changes in concentration ratios of (a) DMS to chlorophyll $a$ and (b) DMS to DMSPp in the unamended and nutrient-treated carboys during a mesocosm experiment with seawater from the Mobile Bay plume

\section{DMS:chl $a$ and DMS:DMSPp}

The proportional increase in DMS concentrations in both carboys was significantly more than that of chl a or DMSPp. This is illustrated by the increasing trend of the ratios DMS:chl a or DMS:DMSPp plotted against time of incubation in Fig. 2. These ratios increased 12and 9-fold, respectively, during the incubation and remained high on the last days of the experiment despite rapid DMS consumption and diminishing DMS concentrations on Days 6 through 9. Interestingly, normalization of DMS concentrations to the algal biomass parameters, chl a or DMSPp, removed most of the obvious differences between the unamended and +nutrient carboys. These analyses suggest that DMS concentrations in algal blooms depend on algal biomass and DMSPp but in a distinctly non-linear way. Our findings are consistent with field data sets collected over large geographic regions, which show that variations in chl a concentrations often explain less than $30 \%$ of the variance in DMS concentrations (Andreae 1990, Kettle et al. 1999). In this regard, it is interesting to note that Uher et al. (2000) found that DMS:chl a from various sites in the North Atlantic varied with a regular sine wave-like pattern over an annual cycle, with maxima in mid- to late-summer. The summer DMS:chl a maximum in the field might be related to mixing layer depth, as suggested by Simó \& Pedró-Alió (1999a). In our laboratory study we observed the highest DMS:chl $a$ and DMS:DMSPp ratios during the decline phases of the blooms (Fig. 2), suggesting a major role of grazing and phytoplankton senescence in maintaining high biomass-specific DMS concentrations, as has been suggested before (Leck et al. 1990, Matrai \& Keller 1993). Despite the relatively high DMS concentrations we observed in the coastal water mesocosms, it should be noted that the DMS:chl a ratios $(<1.5)$ were very much lower than the values of 5-20 observed in shelf and oceanic waters of the North Atlantic (Uher et al. 2000).

\section{Temporal changes in DMS consumption rate constants}

The total rate constant for biological DMS consumption, as determined with ${ }^{35} \mathrm{~S}-\mathrm{DMS}$, was initially about $0.73 \mathrm{~d}^{-1}$ in the unamended carboy and declined as the bloom developed and as DMS concentrations increased (Fig. 1c). The lowest rate constant in the unamended carboy $\left(0.25 \mathrm{~d}^{-1}\right)$ was measured on Day 6, when DMS concentration was the highest. After Day 6, the rate constant increased to $0.66 \mathrm{~d}^{-1}$, which was nearly the initial value. Due to logistical problems at the outset of the experiment, the DMS consumption rate constant in the +nutrient carboy was not measured 
until Day 3, when, at $0.37 \mathrm{~d}^{-1}$, it was similar to that in the unamended carboy (Fig. 1d). Thereafter the rate constant in the +nutrient carboy increased and was higher than in the unamended carboy, eventually reaching $0.95 \mathrm{~d}^{-1}$ on Day 9. The higher DMS consumption rate constants late in the +nutrient bloom could have resulted from the generally higher bacterial production in this carboy on Days 4-9 (see Fig. 4), or it might have been a specific response of DMS-consuming bacteria to higher DMS concentrations in the +nutrient bloom. The relatively low DMS consumption rate constants observed when DMS concentrations were increasing, near the top and early decline of the blooms, correspond to longer turnover times for DMS (turnover time $=1 /$ rate constant). The results from both carboys suggests a relatively slow response of the biological consumption processes which led to uncoupling between DMS production and consumption and to the accumulation of DMS. The rate constants measured here with the ${ }^{35} \mathrm{~S}-\mathrm{DMS}$ technique $\left(0.25\right.$ to $\left.0.95 \mathrm{~d}^{-1}\right)$ are similar to those measured previously in various marine waters with inhibitor techniques (Kiene \& Bates 1990, Simó \& Pedrós-Alió 1999b, Wolfe et al. 1999). In general, the rate constants for biological DMS removal from the ocean mixed-layer are greater than those for removal by air-sea exchange (Kiene \& Bates 1990, Kieber et al. 1996, Kwint et al. 1996) pointing to the importance of biological removal in controlling DMS emissions. However, the findings of Kieber et al. (1996) and Simó \& Pedros-Alió (1999b) have emphasized that the relative importance of DMS sink processes can vary in space and time. In our study, the only relevant DMS sink was biological consumption and this process must have been responsible for lowering the DMS concentrations after Day 6, as the blooms declined (Fig. 1c,d).

\section{Temporal changes in DMS consumption}

The biological consumption rate of DMS (product of the consumption rate constant and the DMS concentration) in the unamended carboy increased from 0.8 to $3.1 \mathrm{nM} \mathrm{d}^{-1}$, held roughly steady at this rate from Days 4-8, and then increased to $5.5 \mathrm{nM} \mathrm{d}^{-1}$ on Day 9 (Fig. 1c). DMS consumption in the +nutrient carboy was similar to that in the unamended carboy on Day 3 , but then increased markedly above the unamended carboy on Days 4 through 8, with a maximal rate of $9.1 \mathrm{nM} \mathrm{d}^{-1}$ on Day 6 (Fig. 1d). The rate on Day 9 $\left(4.7 \mathrm{nM} \mathrm{d}^{-1}\right)$ was nearly the same as in the unamended carboy, and DMS consumption in both carboys at the end of the experiment was substantially higher than at the start, controlled primarily by the higher DMS concentrations (i.e. rates constants were similar to the
Day zero value in the unamended carboy). Our findings agree with those of previous studies employing mesocosms (Kwint et al. 1996) or time-series from coastal areas (van Duyl et al. 1998) and open-ocean blooms (Zubkov et al. 2002), which observed that DMS consumption activity increases in response to higher DMS concentrations.

\section{Time trajectory of DMS consumption versus DMS concentration}

DMS consumption rates clearly depended on DMS concentrations as the latter changed with time during the experiment (Fig. 3). For the most part, this concentration dependence was maintained as concentrations rose and fell, as indicated by the trajectories of values from each successive day of sampling. DMS consumption appeared to saturate at about 5-10 nM DMS in the unamended carboy (Fig. 3), but no such saturation was evident in the +nutrient carboy. Previous studies have observed saturation of seawater DMS consumption activity at low nanomolar concentrations (Kiene 1992, Wolfe \& Kiene 1993). The data collected here suggest that the maximum consumption rates for DMS at a particular DMS concentration were stimulated by the nutrient amendment (and the resulting enhancement of phytoplankton biomass and bacterial production). This is further suggested by the fact that during the initial decline of the bloom (Day 6), maximum DMS concentrations were only $40 \%$ higher in the +nutrient

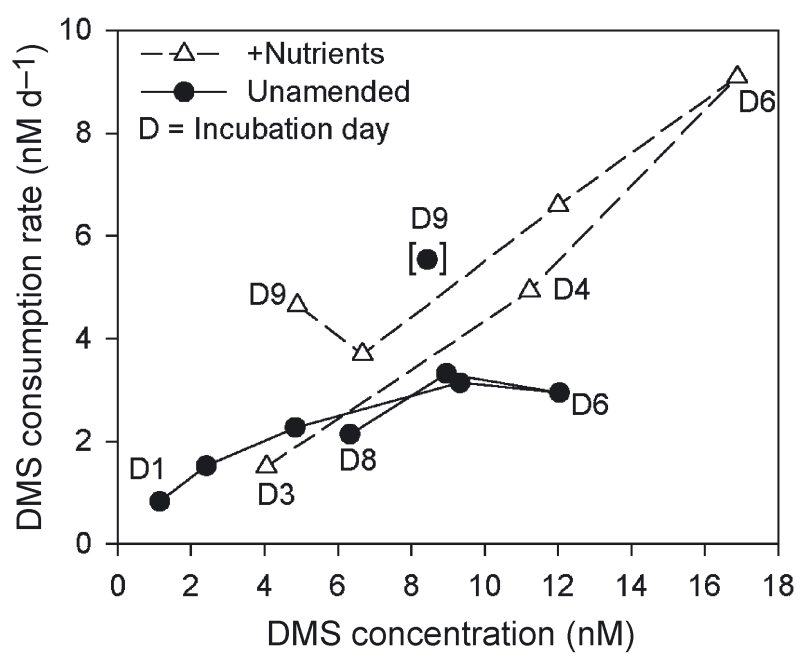

Fig. 3. DMS consumption rates plotted against corresponding DMS concentrations for all measurements obtained from the unamended and +nutrients carboys. Data points for each carboy are connected, indicating time trajectory of consumption rates from Day 1 (D1) to end of the incubation (D9). No data were available for Day 5. For clarity, the line for the unamended carboy was not extended to the D9 point 
carboy than in the unamended carboy, whereas DMS turnover in the +nutrient carboy was $300 \%$ higher than in the unamended carboy. Thus, there was tighter coupling of DMS production and consumption in the +nutrients bloom, with DMS consumption playing a significant role in limiting the accumulation of DMS.

\section{Fate of DMS}

On average, $90 \%$ of the DMS consumption resulted in production of dissolved non-volatile products; therefore the time courses of DMS turnover into DNVS (not shown) looked nearly identical to that of total DMS turnover (see Fig. 1c,d). These findings agree with previous studies that found DNVS (Zubkov et al. 2002) including sulfate (i.e. DNVS; Kiene \& Linn 2000b) to be the major non-volatile transformation products of DMS.

The rate of DMS-sulfur incorporation into bacterial biomass was a relatively small fraction (4-22\%; mean $=10 \pm 5 \%$ ) of the total DMS consumption rate in both blooms. The rate of DMS-sulfur assimilation increased sharply during the decline of the nutrientamended bloom (Fig. 4b), whereas it was relatively steady in the unamended bloom (Fig. 4a). The higher DMS-sulfur turnover into bacterial biomass in the +nutrients bloom corresponded with generally higher bacterial biomass production occurring during the later stages of the +nutrients bloom (Fig. 4b). The incorporation of sulfur from DMS into microbial biomass was probably due to use of the reduced sulfur for protein synthesis, as has been shown previously for DMSP (Kiene et al. 1999). Tests with a variety of other water samples have consistently shown that DMSsulfur is incorporated into a macromolecular fraction (R. Kiene unpubl. data). In the present study the sulfur
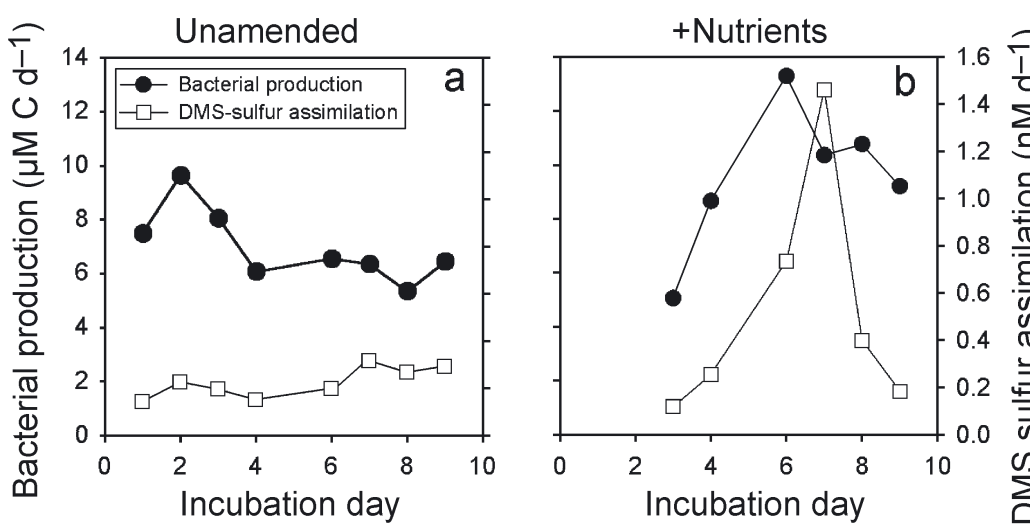

Fig. 4. Time course of heterotrophic bacterial production and DMS-sulfur assimilation into particulate material in unamended and nutrient-amended carboys. Note that bacterial production scale on left ordinate and the DMS sulfur assimilation scale on far right ordinate applies to both (a) and (b) assimilation efficiency from DMS ( 10\%) was consistently lower than previously observed for DMSPd in coastal waters $(20-39 \%)$, but similar to that for DMSP in oceanic waters (Kiene \& Linn 2000b). Using our values of DMS sulfur assimilation, and estimates of bacterial sulfur demand derived from bacterial carbon production and a cellular C:S ratio of 248 (Cuhel et al. 1982), we calculated that DMS contributed a relatively small amount $(0.3-3.4 \%)$ to the bacterial sulfur demand in both blooms. Such low contributions contrast with those measured previously for dissolved DMSP, which may contribute $50-100 \%$ of the bacterial sulfur demand in ocean waters (Kiene \& Linn 2000a, Zubkov et al. 2002).

Few previous studies have examined the biological fate of DMS in seawater. Wolfe \& Kiene (1993) used ${ }^{14} \mathrm{C}$-labeled DMS in waters from a salt marsh and found that the methyl carbons were assimilated into biomass and respired to $\mathrm{CO}_{2}$ in roughly equal proportions (i.e. $50 \%$ carbon assimilation efficiency). Based on this limited amount of information, it appears that the sulfur in DMS may be assimilated to a much lesser degree $(\sim 10 \%)$ than the carbon of DMS.

\section{Production, abundance and composition of heterotrophic bacterioplankton}

The increases of phytoplankton biomass in both blooms significantly increased bacterial production and abundance (Figs. 4 \& 5). Bacterial biomass production in the unamended bloom peaked at $9 \mu \mathrm{mol} \mathrm{C} \mathrm{^{-1 }}$ $\mathrm{d}^{-1}$ on Day 2 (Fig. 4a), which was the same day as the chlorophyll maximum. After the peak it slowly

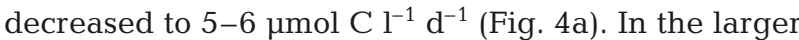
bloom, with added nutrients, bacterial production

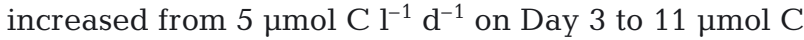
$\mathrm{l}^{-1} \mathrm{~d}^{-1}$ on Day 6 . The peak of bacterial production in the +nutrients carboy occurred $2 \mathrm{~d}$ after the highest chl a concentrations, but on the same day (Day 6) as the maximum DMS concentration and highest DMS consumption. After the maximum, bacterial production remained higher in the +nutrients carboy than in the unamended carboy (Fig. 4b).

The abundance of heterotrophic bacterioplankton (HB) in the unamended

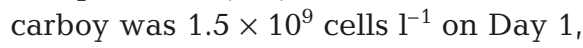
and it peaked at $5 \times 10^{9}$ cells ${ }^{-1}$ in the unamended carboy on Day 5 and at

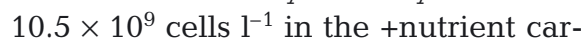
boy on the Day 7 (Fig. 5 a,b). These maxima in bacterial cell abundances 

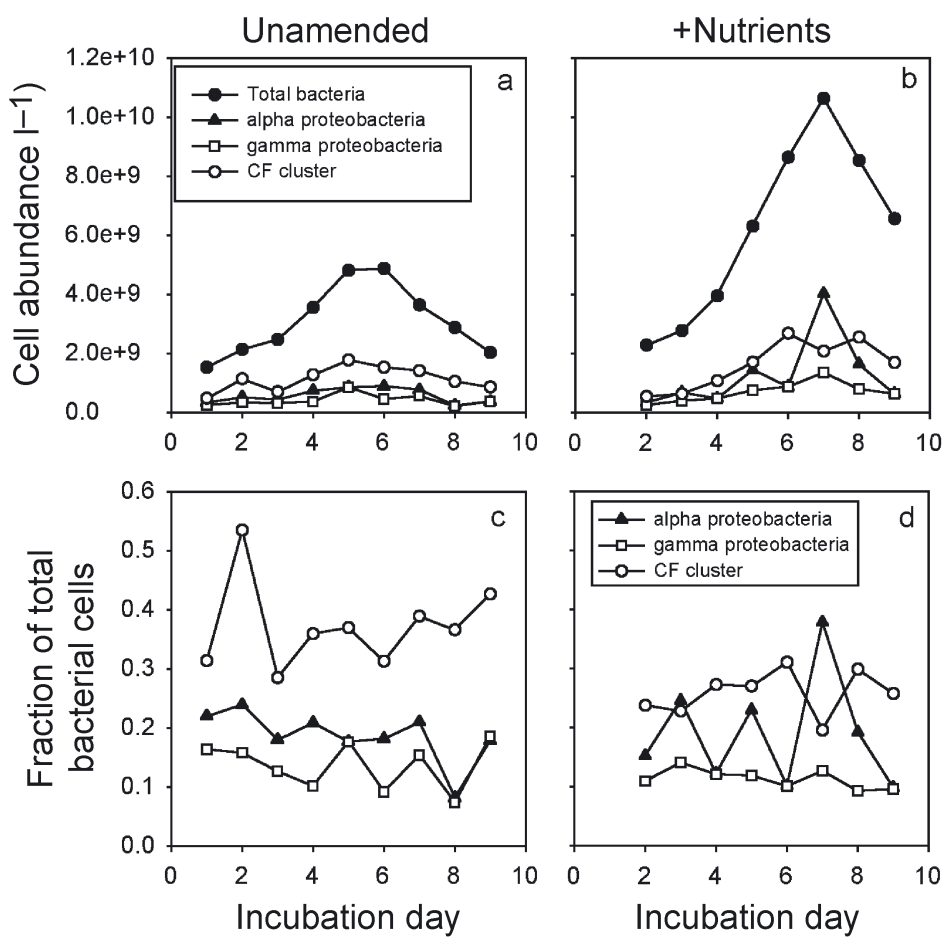

Fig. 5. Time-dependent changes in total heterotrophic bacterial abundance and concentrations of dominant groups of bacterioplankton, Cytophaga-Flavobacterium (CF) cluster, $\alpha$-subdivision, and $\gamma$-subdivision of the Proteobacteria in (a) unamended and (b) nutrient-amended carboys, and relative abundances of identified groups in (c) unamended and (d) +nutrients carboy. Maximum error for phylogenetic counts was estimated to be $5.5 \%$

occurred several days after the peak of chl a in each respective carboy. Towards the end of the experiment, bacterial abundances in the unamended carboy decreased to the initial level. HB abundance in the +nutrient bloom also declined toward the end of the experiment, but on the last day of sampling remained higher $\left(6 \times 10^{9}\right.$ cells $\left.\mathrm{l}^{-1}\right)$ than in the unamended carboy.

The increases in bacteria-associated parameters (production and numbers) were larger in the more intense bloom (+nutrients). These results are not surprising, since numerous studies have shown that bacteria are stimulated by DOM released from phytoplankton (Larsson \& Hagstrom 1982). Higher DMS concentrations and DMS consumption in the +nutrient carboy generally corresponded to the higher values of HB abundances, and biomass production. However, direct correlations of these parameters were not significant, most likely due to temporal offsets in the development of the biological communities and the biogeochemical processes. In general agreement with our findings, Kwint \& Kramer (1995) and Kwint et al. (1996) reported that most-probable number counts of DMS-consuming bacteria in mesocosms increased late in the bloom cycles, and were probably responsible for significant removal of DMS.

Despite the significant temporal changes in total bacterial abundance and activity, the community composition changed relatively little, based upon the major group-specific measurements we made. Because we used probes targeting only large phylogenetic groups of bacteria, we cannot exclude the possibility of species changes within individual groups, which would have gone undetected. The concentration of identified bacterial groups rose and fell during the bloom cycles in both carboys (Fig. 5a,b) and their relative abundances changed moderately over time (Fig. 5c,d). Of the identified groups the Cytophaga-Flavobacterium (CF) cluster bacteria generally had the highest concentrations, increasing from $0.5 \times 10^{6}$ cells $\mathrm{ml}^{-1}$ to $2 \times 10^{6}$ cells $\mathrm{ml}^{-1}$ in the unamended carboy and to $3 \times 10^{6}$ cells $\mathrm{ml}^{-1}$ on the Day 6 in the +nutrient carboy (Fig. 5 a,b). These CF cluster abundances corresponded to $32 \pm 8 \%$ of all bacterial cells, with somewhat higher relative abundances in the unamended carboy. The concentrations of $\alpha$ - and $\gamma$-proteobacteria were lower than those of the CF cluster (Fig. 5 a,b), with bacteria from the $\alpha$-subdivision making up $18 \pm 7 \%$ of the total numbers and with bacteria from the $\gamma$-subdivision making up $13 \pm$ $3 \%$ of the total bacteria (Fig. $5 \mathrm{c}, \mathrm{d}$ ). Bacteria from the $\beta$-subdivision of Proteobacteria comprized $<3 \%$ of the total abundances (data not shown). Somewhat more pronounced changes in community composition were observed in the +nutrient carboy. There was a peak of $\alpha$-proteobacteria abundance on Day 7 in the +nutrient carboy (Fig. 5b) and this was the dominant group on that day. The concentration of $\gamma$-proteobacteria steadily increased to a maximum of $1.4 \times 10^{6}$ cells $\mathrm{ml}^{-1}$ on the same day as the $\alpha$-proteobacteria peak (Fig. 5b), and both groups declined thereafter. The peak of the CF cluster in the unamended carboy occurred on the second day, but it did not correspond to any other parameter measured. In general, the dominance of bacterioplankton communities by members of the CF cluster and $\alpha$ - and $\gamma$-proteobacteria is typical of marine waters (Giovannoni \& Rappe 2000).

Given the relatively minor changes in bacterial community structure, we cannot infer which groups may have been prominent in producing or consuming DMS in this study. Other recent work (González et al. 2000, Zubkov et al. 2001, 2002, Moran et al. 2003) has pointed to the $\alpha$-proteobacteria, particularly members of the Roseobacter clade, as being important DMSP 
consumers in certain oceanic phytoplankton blooms, but they have not been linked with DMS consumption in the field (Zubkov et al. 2002). The $\alpha$-proteobacteria were an important component of the bacterial population in the present study $(18 \pm 7 \%)$, but they came to brief dominance in the +nutrient carboy only on Day 7 . More detailed studies will be required to assign biogeochemical functions to this or other taxonomic groups.

\section{CONCLUSIONS}

During laboratory-induced phytoplankton blooms, DMS concentrations increased proportionally more than phytoplankton biomass (chl a) or its precursor (DMSPp), resulting in increases of the ratios DMS:chl a and DMS:DMSPp. DMS concentrations increased early in the bloom cycle, due mainly to a slow response of the consumption process, which was unable to tightly control the DMS concentrations. After reaching maximal concentrations during the decline phase of the blooms, DMS concentrations were eventually lowered by increased biological consumption. DMS-sulfur was transformed predominantly into dissolved non-volatile products, with incorporation into particulates accounting for only $\sim 10 \%$ of the transformed DMS-sulfur. Higher concentrations and turnover of DMS roughly corresponded with higher abundances and production of bacterioplankton. However, despite rather large changes in abundance and activity of the bacterioplankton, the relative abundances of 3 dominant groups: the Cytophaga-Flavobacterium cluster, $\alpha$ - and $\gamma$-proteobacteria, remained relatively constant throughout the phytoplankton bloom cycle and no inferences could be made as to their role in DMSP/DMS cycling in the low DMSPp:chl a blooms studied.

Acknowledgements. M.Z. thanks the Dauphin Island Sea Lab for providing housing during his visit. This study was funded by the Chemical Oceanography program of the NSF through grant OCE-9907471. We are also grateful to the Max-Planck Society for the support of this work. The research of M.Z. was supported by a postdoctoral research fellowship (GT5/98/ 16/MSTB) from the UK Natural Environment Research Council.

\section{LITERATURE CITED}

Amann RI, Ludwig W, Schleifer KH (1995) Phylogenetic identification and in situ detection of individual microbial cells without cultivation. Microbiol Rev 59:143-169

Andreae MO (1990) Ocean-atmosphere interactions in the global biogeochemical sulfur cycle. Mar Chem 30:1-29

Bates TS, Kiene RP, Wolfe GV, Matrai PA, Chavez FP, Buck KR, Blomquist BW, Cuhel RL (1994) The cycling of sulfur in surface sea water of the Northeast Pacific. J Geophys
Res 99:7835-7843

Charlson RJ, Lovelock JE, Andreae MO, Warren SG (1987) Oceanic phytoplankton, atmospheric sulfur, cloud albedo and climate. Nature 326:655-661

Cuhel RL, Taylor CD, Jannasch HW (1982) Assimlatory sulfur metabolism in marine microorganisms: sulfur metabolism, protein synthesis, and growth of Alteromonas luteoviolaceus and Pseudomonas halodurans during perturbed batch growth. Appl Environ Microbiol 43:151-159

Gibson JAE, Swadling KM, Burton HR (1996) Acrylate and DMSP concentrations during an antarctic phytoplankton bloom: new sources of reduced sulphur compounds. In: Kiene RP, Visscher PT, Keller MD, Kirst GO (eds) Biological and environmental chemistry of DMSP and related sulfonium compounds, Plenum Press, New York, p 213-222

Giovannoni S, Rappe M (2000) Chap 3: Evolution, diversity and molecular ecology of marine prokaryotes. In: Kirchman D (ed) Microbial ecology of the oceans, John Wiley \& Sons, New York, p 1-21

Glöckner FO, Amann R, Alfrieder A, Pernthaler J, Psenner R, Trebesius K, Schleifer KH (1996) An in situ hybridization protocol for detection and identification of planktonic bacteria. Syst Appl Microbiol 19:403-406

González JM, Simó R, Massana R, Covert JS, Casamayor EO, Pedrós-Alió C, Moran MA (2000) Bacterial community structure associated with a dimethylsulfoniopropionateproducing north Atlantic bloom. Appl Environ Microbiol 66:4237-4246

Iverson RL, Nearhoof FL, Andreae MO (1989) Production of dimethylsulfonium propionate and dimethylsulfide by phytoplankton in estuarine and coastal waters. Limnol Oceanogr 34:53-67

Keller MD, Bellows WK, Guillard RRL (1989) Dimethyl sulfide production in marine phytoplankton. In: Saltzman E, Cooper WJ (eds) Biogenic sulfur in the environment. American Chemical Society, New York, p 167-182

Kettle AJ, Andreae MO (2000) Flux of dimethylsulfide from the oceans: a comparison of updated data sets and flux models. J Geophys Res 105:26793-26808

Kettle AJ, Andreae MO, Amouroux D, Andreae TW and 28 others (1999) A global database of sea surface dimethylsulfide (DMS) measurements and a procedure to predict sea surface DMS as a function of latitude, longitude, and month. Glob Biogeochem Cycles 13:399-444

Kieber DJ, Jiao J, Kiene RP, Bates TS (1996) Impact of dimethylsulfide photochemistry on methyl sulfur cycling in the Equatorial Pacific Ocean. J Geophys Res 101: $3715-3722$

Kiene RP (1992) Dynamics of dimethyl sulfide and dimethylsulfoniopropionate in oceanic seawater samples. Mar Chem 37:29-52

Kiene RP (1996a) Production of methanethiol from dimethylsulfoniopropionate in marine surface waters. Mar Chem $54: 69-83$

Kiene RP (1996b) Turnover of dissolved DMSP in estuarine and shelf waters from the Northern Gulf of Mexico. In: Kiene RP, Visscher PT, Keller MD, Kirst GO (eds) Biological and environmental chemistry of DMSP and related sulfonium compounds. Plenum Press, New York, p 337-349

Kiene RP, Bates TS (1990) Biological removal of dimethyl sulphide from seawater. Nature 345:702-705

Kiene RP, Linn LJ (2000a) Distribution and turnover of dissolved DMSP and its relationship with bacterial production in the Gulf of Mexico. Limnol Oceanogr 45: 849-861

Kiene RP, Linn LJ (2000b) The fate of dissolved dimethylsulfoniopropionate (DMSP) in seawater: tracer studies 
using ${ }^{35}$ S-DMSP. Geochim Cosmochim Acta 64:2797-2810

Kiene RP, Linn LJ, González J, Moran MA, Bruton JA (1999) Dimethylsulfoniopropionate and methanethiol are important precursors of methionine and protein-sulfur in marine bacterioplankton. Appl Environ Microbiol 65:4549-4558

Kiene RP, Linn LJ, Bruton JA (2000) New and important roles for DMSP in marine microbial communities. J Sea Res 43:209-224

Kirchman DL, K'nees E, Hodson R (1985) Leucine incorporation and its potential as a measure of protein synthesis by bacteria in natural aquatic systems. Appl Environ Microbiol 49:599-607

Kwint RL, Kramer KJM (1995) Dimethylsulphide production by plankton communities. Mar Ecol Prog Ser 121:227-237

Kwint RLJ, Quist P, Hansen TA, Dijkhuizen L, Kramer KJM (1996) Turnover of dimethylsulfoniopropionate and dimethylsulfide in the marine environment: a mesocosm experiment. Mar Ecol Prog Ser 145:223-232

Larsson U, Hagstrom A (1982) Fractionated phytoplankton primary production, exudate release and bacterial production in a Baltic eutrophication gradient. Mar Biol 67: $57-70$

Leck C, Larsson U, Bagender LE, Johansson S, Hajdu S (1990) Dimethyl sulfide in the Baltic Sea: annual variability in relation to biological activity. J Geophys Res 95:3353-3364

Malin G, Kirst GO (1997) Algal production of dimethyl sulfide and its atmospheric role. J Phycol 33:889-896

Malin G, Turner S, Liss PS, Holligan P, Harbour D (1993) Dimethyl sulfide and dimethylsulphoniopropionate in the Northeast Atlantic during the summer coccolithophore bloom. Deep-Sea Res 40:1487-1508

Matrai PA, Keller MD (1993) Dimethylsulfide in a large-scale coccolithophore bloom in the Gulf of Maine. Contin Shelf Res 13:831-843

Matrai PA, Vernet M (1997) Dynamics of the vernal bloom in the marginal ice zone of the Barents Sea: dimethylsulfide and dimethylsulfoniopropionate budgets. J Geophys Res 102:22965-22979

Moran MA, Gonzalez JM, Kiene RP (2003) Linking a bacterial taxon to sulfur cycling in the sea: studies of the marine Roseobacter group. Geomicrobiol J 20:375-388

Nguyen BC, Belviso S, Mihalopoulos N (1988) Dimethyl sulfide production during natural phytoplankton blooms. Mar Chem 24:133-141

Pennock JR, Goyer JN, Herrera-Silveira JA, Iverson RL, Whitledge TE, Mortazavi B, Comin FA (1999) Nutrient behavior and phytoplankton production in Gulf of Mexico estuaries. In: Bianchi TS, Pennock JR, Twilley RR (eds) Biogeochemisty of Gulf of Mexico estuaries. John Wiley \& Sons, New York, p 109-162

Simó R (2001) Production of atmospheric sulfur by oceanic plankton: biogeochemical, ecological and evolutionary links. Trends Ecol Evol 16:287-294

Simó R, Pedrós-Alió C (1999a) Role of vertical mixing in

Editorial responsibility: Otto Kinne (Editor), Oldendorf/Luhe, Germany controlling the oceanic production of dimethyl sulphide. Nature 402:396-399

Simó R, Pedrós-Alió C (1999b) Short-term variability in the open ocean cycle of dimethylsulfide. Glob Biogeochem Cycles 13:1173-1181

Simó R, Archer SD, Pedrós-Alió C, Gilpin L, Stelfox-Widdicombe CE (2002) Coupled dynamics of dimethylsulfoniopropionate and dimethylsulfide cycling and the microbial food web in surface waters of the North Atlantic. Limnol Oceanogr 47:53-61

Simon M, Azam F (1989) Protein content and protein synthesis rates of planktonic marine bacteria. Mar Ecol Prog Ser 51:201-213

Steinke M, Daniel C, Kirst GO (1996) DMSP lyase in marine micro- and macroalgae: intraspecific differences in cleavage activity. In: Kiene RP, Visscher PT, Keller MD, Kirst GO (eds) Biological and environmental chemistry of DMSP and related sulfonium compounds. Plenum Press, New York, p 317-324

Strickland JDH, Parsons TR (1968) A practical handbook of seawater analysis. Fish Res Board Can 167

Turner SM, Malin G, Liss PS, Harbour DS, Holligan PM (1988) The seasonal variation of dimethyl sulfide and dimethylsulfoniopropionate concentrations in nearshore waters. Limnol Oceanogr 33:364-375

Uher G, Schebeske G, Barlow RG, Cummings DG, Mantoura RFC, Rapsomankiks SR, Andreae MO (2000) Distribution and air-sea exchange of dimethyl suphide at the European western continental margin. Mar Chem 69:277-300

van Duyl FC, Gieskes WWC, Kop AJ, Lewis WE (1998) Biological control of short-term variation in the concentration of DMSP and DMS during a Phaeocystis spring bloom. J Sea Res 40:221-231

Wolfe GV, Kiene RP (1993) Radioisotope and chemical inhibitor measurements of dimethyl sulfide consumption rates and kinetics in estuarine waters. Mar Ecol Prog Ser 99:261-269

Wolfe GV, Levasseur M, Cantin G, Michaud S (1999) Microbial consumption and production of dimethyl sulfide (DMS) in the Labrador Sea. Aquat Microb Ecol 18:197-205

Zubkov MV, Fuchs BM, Eilers H, Burkill PH, Amann R (1999) Determination of total protein content of bacterial cells by SYPRO staining and flow cytometry. Appl Environ Microbiol 65:3251-3257

Zubkov MV, Fuchs BM, Archer SD, Kiene RP, Amann R, Burkill PH (2001) Linking the composition of bacterioplankton to rapid turnover of dissolved dimethylsulphoniopropionate in an algal bloom in the North Sea. Environ Microbiol 3:304-311

Zubkov MV, Fuchs BM, Archer SD, Kiene RP, Amann R, Burkill PH (2002) Rapid turnover of dissolved DMS and DMSP by defined bacterioplankton communities in the stratified euphotic zone of the North Sea. Deep-Sea Res Part II 49:3017-3038

Submitted: July 10, 2001; Accepted: December 31, 2003 Proofs received from author(s): April 14, 2004 